\title{
Modeling Yield Losses and Fungicide Profitability for Managing Fusarium Head Blight in Brazilian Spring Wheat
}

\author{
Maíra Rodrigues Duffeck, ${ }^{1}$ Kaique dos Santos Alves, ${ }^{1}$ Franklin Jackson Machado, ${ }^{1}$ Paul David Esker, ${ }^{2}$ \\ and Emerson Medeiros Del Ponte ${ }^{1, \dagger}$ \\ ${ }^{1}$ Departamento de Fitopatologia, Universidade Federal de Viçosa, Viçosa, MG 36570-900 Brazil \\ ${ }^{2}$ Department of Plant Pathology and Environmental Microbiology, The Pennsylvania State University, University Park, PA 16802, U.S.A. \\ Accepted for publication 7 November 2019.
}

ABSTRACT

\begin{abstract}
Fusarium head blight (FHB) and wheat yield data were gathered from fungicide trials to explore their relationship. Thirty-seven studies over 9 years and 11 locations met the criteria for inclusion in the analysis: FHB index in the untreated check $\geq 5 \%$ and the range of index in a trial $\geq 4$ percentage points. These studies were grouped into two baseline yields, low $\left(Y l \leq 3,631 \mathrm{~kg} \mathrm{ha}^{-1}\right)$ or high $\left(Y h>3,631 \mathrm{~kg} \mathrm{ha}^{-1}\right)$, defined based on the median of maximum yields across trials. Attainable (disease-free) yields and FHB index were predicted using a wheat crop and a disease model, respectively, in 280 simulated trials (10 planting dates in a 28 -year period, 1980 to 2007) for the Passo Fundo location. The damage coefficient was then used to calculate FHB-induced yield loss (penalizing attainable yield) for each experiment. Losses were compared between periods defined as before and after FHB resurge during the early 1990s. Disease reduction from the use of one or two sprays of a triazole fungicide (tebuconazole) was also simulated, based on previous meta-analytic estimates, and the response
\end{abstract}

in yield was used in a profitability analysis. Population-average intercepts but not the slopes differed significantly between $Y l\left(2,883.6 \mathrm{~kg} \mathrm{ha}^{-1}\right)$ and $Y h$ $\left(4,419.5 \mathrm{~kg} \mathrm{ha}^{-1}\right)$ baseline yields and the damage coefficients were $1.60 \%{ }^{-1}$ and $1.05 \%{ }^{-1}$, respectively. The magnitudes and trends of simulated yield losses were in general agreement with literature reports. The risk of not offsetting the costs of one or two fungicide sprays was generally higher $(>0.75)$ prior to FHB resurgence but fungicide profitability tended to increase in recent years, depending on the year. Our simulations allowed us to reproduce trends in historical losses, and may be further adjusted to test the effect and profitability of different control measures (host resistance, other fungicides, etc.) on quality parameters such as test weight and mycotoxin contamination, should the information become available.

Keywords: crop losses, ecology and epidemiology, metaanalysis, Triticum aestivum, wheat scab
Fusarium head blight (FHB) is a damaging disease of wheat and barley that affects yield and contaminates grains with mycotoxins produced by the fungus (Goswami and Kistler 2004; McMullen et al. 1997). FHB has been considered a resurgent problem worldwide since the early 1990s, with economic losses estimated at approximately $\$ 2.7$ billion in the United States over a two-decade period (McMullen et al. 2012). Similar patterns have been reported in wheat and barley regions in South America, where the frequency of FHB epidemics increased during the 1990s compared with the previous two decades (Del Ponte et al. 2009; Fernandes 1997; Moschini et al. 2013). Two hypotheses for the increase in FHB importance include the wider adoption of conservation tillage practices, as well as the increased use of corn-wheat rotations in North America and Europe (Landschoot et al. 2013; Schaafsma et al. 2005). In Brazil, modeling work also showed a significant contribution of climate variability to the resurgence of FHB based on analysis of a 50-year weather dataset for a location in southern Brazil (Del Ponte et al. 2009).

\section{†Corresponding author: E. M. Del Ponte; delponte@ufv.br}

Funding: Research conducted by P. Esker was also supported by the United States Department of Agriculture National Institute of Food and Agriculture (1016474) and Federal Appropriations under Project PEN04660. Further support was provided by Coordenação de Aperfeiçoamento de Pessoal de Nível Superior (PROEX) and Conselho Nacional de Desenvolvimento Científico e Tecnológico (PQ 306857/ 2015-4). M. R. Duffect and E. M. Del Ponte are thankful to CAPES and CNPq for the scholarship and research fellow support, respectively.

*The $\boldsymbol{e}$-Xtra logo stands for "electronic extra" and indicates that two supplementary tables are published online.

The author(s) declare no conflict of interest.

(C) 2020 The American Phytopathological Society
The occurrence and intensity of FHB epidemics are driven by the amount of airborne inoculum (primarily ascospores) dispersed from both within and outside the field, combined with humid conditions around anthesis (McMullen et al. 2012). Disease control is best achieved through the use of integrated practices, including cultural measures aimed at reducing local inoculum, the use of moderately resistant cultivars and fungicide sprays (Wegulo et al. 2011). Although chemical fungicides, mainly of the triazole chemistry, have been recommended for controlling FHB, the efficacy levels are generally modest and influenced by the type of active ingredient, wheat cultivar, number of sprays, and application technology (Edwards and Godley 2010; Machado et al. 2017; Paul et al. 2008; Willyerd et al. 2012).

Coinciding with the resurgence of FHB, research conducted since the mid-1990s has focused on evaluating a range of control methods, including host resistance and fungicide sprays, all with the explicit goal to reduce mycotoxin contamination and protect wheat yields. Thus, these efforts have generated an increased amount of epidemiological data (McMullen et al. 2012; Machado et al. 2017; Shah et al. 2018). These large data sets have enabled the use of metaanalytic approaches to study the effects of fungicides on disease control, yield increase, and mycotoxin reduction, as well as to explore empirical relationships between FHB index and wheat yield or mycotoxin levels (Madden and Paul 2009; Salgado et al. 2011, 2014, 2015). Meta-analysis has become standard for studying empirical relationships between disease and yield data for other diseases such as soybean rust (Dalla Lana et al. 2015), soybean white mold (Lehner et al. 2017), and soybean target spot (Edwards Molina et al. 2018).

The majority of studies on the relationship between FHB intensity and other variables such as yield, test weight, and mycotoxin contamination have been conducted in the temperate regions in North American cropping conditions (Madden and Paul 2009; Salgado et al. 2011), where several abiotic and biotic conditions 
may differ from the subtropics of South America, including management practices (Del Ponte et al. 2015; Spolti et al. 2014). In North America, the relationship between FHB index and yield has been studied using field trial data obtained from multiple location-years to estimate damage coefficients $(D c)$ (percent reduction in yield per percent point increase in FHB index), which varied for winter wheat (Madden and Paul 2009; Salgado et al. 2015) and spring wheat (Madden and Paul 2009).

In Brazil, previous efforts to estimate yield losses due to FHB used a destructive random sampling of wheat heads in replicated nontreated plots of field experiments to estimate attainable yield (weight of disease-free spikes per sample weight) and actual yield (sample weight), with losses estimated in both absolute and relative terms. Using this method, mean yield losses for the period 1999 to 2010 were estimated at higher levels compared with 1984 to 1994 (Panisson et al. 2003; Reis and Carmona 2013; Reis et al. 1996). Since the early 2010s, significant yield reductions due to FHB have been reported in nontreated plots from a network of uniform fungicide trials (UFTs) (Santana et al. 2012, 2014, 2016a,b,c). A recent meta-analysis of the effect of fungicides on FHB control and yield using data from several sources, including peer-reviewed articles published since the year 2000 and the UFT data from Brazil, explored yield responses and economic benefits from using fungicides. Results of that study suggested that a spray of a triazole fungicide could be profitable, depending on disease risk, but only taking yield responses, not wheat quality parameters, into account (Machado et al. 2017).

Although several studies have highlighted the impact of FHB on wheat in Brazil, the heterogeneity of the functional relationship between FHB intensity and wheat yield has not been explored for our conditions. Although knowledge is available for studies conducted in North America, it is not known whether the $D c$ are valid for our conditions of high and low baseline yields in spring wheat, a hypothesis that we tested in this study. Once the relationship is established, $D c$ could be useful as a nondestructive method for predicting FHB index and improving the risk assessment of economic losses due to FHB.

The primary objective of this study was to model the relationship between a single (critical-point) assessment of FHB index and wheat yield data obtained from independent studies in order to obtain estimates of $D c$ in a manner similar to other previously published studies (Edwards Molina et al. 2018; Lehner et al. 2017; Madden and Paul 2009; Salgado et al. 2015). A secondary objective was to use the $D c$ to reconstruct yield loss curves in a 28 -year time series by coupling wheat yield and disease model, and further calculating the profitability of fungicide applications to reduce predicted yield loss, not the quality parameters, for a range of wheat prices and fungicide costs for each year.

\section{MATERIALS AND METHODS}

Data source, description, and criteria for inclusion. A systematic review of peer- and non-peer-reviewed articles and reports published after the year 2000 was conducted to identify studies reporting wheat yield and FHB intensity data in Brazil. In total, 29 publications reported results from trials conducted at 23 locations in southern Brazil spanning a 16-year period (2000 to 2016). Altogether, these locations comprise $90 \%$ of the total wheat production in Brazil (CONAB 2018). A portion of these data has been used in a previous study on the effect of fungicides on disease and yield (Machado et al. 2017). In brief, the studies were conducted following a standard protocol and regional recommendations of agronomic practices. FHB disease development was natural in all trials. The number of treatments evaluated in each trial ranged from 5 to 13 (average of 8.5 treatments/trial). All trials included a nontreated control. Fungicides were typically applied once at flowering (Zadok's scale 60 to 64) or twice, the first at flowering and the second 10 days later. The specific fungicide treatments and respective application rates varied among trials (Machado et al. 2017).

The disease response variable used in our study was FHB index (\%), which represents the proportion of diseased spikelets in the sample of spikes (Paul et al. 2005, 2007). This index was assessed during soft dough stage (Zadoks scale 85), prior to senescence. Plots were harvested and the mean yield (kilograms per hectare) was adjusted to $13 \%$ grain moisture. Data from all trials were inspected closely for both FHB index and yield, from which two criteria were defined to select trials for inclusion in the analysis: (i) FHB index in the untreated check of the trial should be at least $5 \%$ (usually the maximum FHB index in the trial) and (ii) the range of FHB index from the largest to smallest value was at least $4 \%$. The latter criterion was adapted from a previous study that used $2 \%$ as the minimum range (Madden and Paul 2009). Twenty-seven trials did not meet these minimum criteria (FHB index values in the untreated check were mostly $<5 \%$ ) and were excluded from subsequent analyses. Influence analysis was also performed and five influential studies, or those that exert a very high influence on the overall results and distort the pooled effect (Viechtbauer and Cheung 2010), were identified and excluded (data not shown). Therefore, data were available for 37 trials reported in 18 studies (Supplementary Table S1).

Effect sizes and meta-analytic modeling. Intercepts $\left(\beta_{0}\right)$ and slopes $\left(\beta_{1}\right)$ (using ordinary least square regression modeling) were estimated for the relationship between FHB index and wheat yield at the trial level (Dalla Lana et al. 2015; Madden and Paul 2009). The interdecile (ID) range summarized the estimates of linear coefficients for each trial (Lehner et al. 2017; Madden and Paul 2009).

A multilevel (random coefficients) model was fitted to the yield-FHB index relationship, and the population-average intercept and slope were estimated as described elsewhere, assuming a linear relationship between FHB index and yield (Lehner et al. 2017; Madden and Paul 2009). The lmer function of the lme4 package of $\mathrm{R}$ was used to estimate the mean effect based on the between-study variance and within-study variance and also to predict the studyspecific intercept $\left(\beta_{0}\right)$ and slope $\left(\beta_{1}\right)$ coefficients, also termed as best linear unbiased predictions (Lehner et al. 2017). A categorical baseline yield was created to represent trials with high yield $(Y h)$ or low yield $(Y l)$ based on the maximum yield achieved in the trial. We used the median of the maximum yield values across trials $(3,631 \mathrm{~kg}$ $\mathrm{ha}^{-1}$ ) as a threshold of baseline yield. Baseline yield was tested as a moderator variable in order to account for the heterogeneity in the intercept or slope of the yield-FHB index relationship. Wald-type tests were performed to determine whether the inclusion of the covariate in the model significantly affected the model coefficients. We obtained a $D c$ (percent reduction in yield in our study) to compare with coefficients determined in other studies. The $D c$ for the $Y l$ and $Y h$ production situations was calculated by dividing the estimated population-average slope $\left(\hat{\beta}_{1}\right)$ (kilograms per hectare per percentage) by the estimated population-average intercept $\left(\hat{\beta}_{0}\right)$ (kilograms per hectare) $\times 100$ (Lehner et al. 2017; Madden and Paul 2009).

Simulation of yield losses. The $D c$ obtained from the metaanalysis was used to calculate actual yield, representing a reduction in attainable yield based on the predicted FHB index obtained by a disease simulation model for the same experiment (Del Ponte et al. 2005; Del Ponte et al. 2009). Percent yield loss was defined as the relative reduction of the attainable yield due to FHB. This was done over the entire time series, encompassing two periods defined as before (pre-1990) and after FHB resurgence in Brazil.

To simulate attainable yield, or the yield constrained only by factors like radiation, temperature, crop phenology, and physiology, as well as water and soil nutrients (Savary et al. 2018), we used a crop simulation model (cropsim-wheat) calibrated with the parameters for a spring wheat cultivar and soil profiles for the conditions of Passo Fundo $\left(28^{\circ} 15^{\prime} 00^{\prime \prime} \mathrm{S}\right.$ and $52^{\circ} 25^{\prime} 12^{\prime \prime} \mathrm{W}$ ) (Lazzaretti et al. 2015). In total, 280 virtual experiments were simulated, combining 
10 planting dates in a 28 -year period (1980 to 2007). The 10 yearly runs were performed using historical daily weather data (minimum and maximum temperature, solar radiation, and rainfall) for a series of sowing dates from 1 to 30 June (spaced 3 days apart), which is the recommended sowing period for Passo Fundo. Starting on the heading date simulated by the wheat model, the FHB model predicted daily infection risks using daily records of rainfall, air relative humidity, and air temperature (Del Ponte et al. 2005). The daily risks were accumulated during the flowering period and further used to predict FHB severity index based on a linear

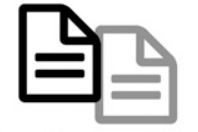

Systematic review

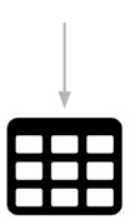

FHB index Wheat yield

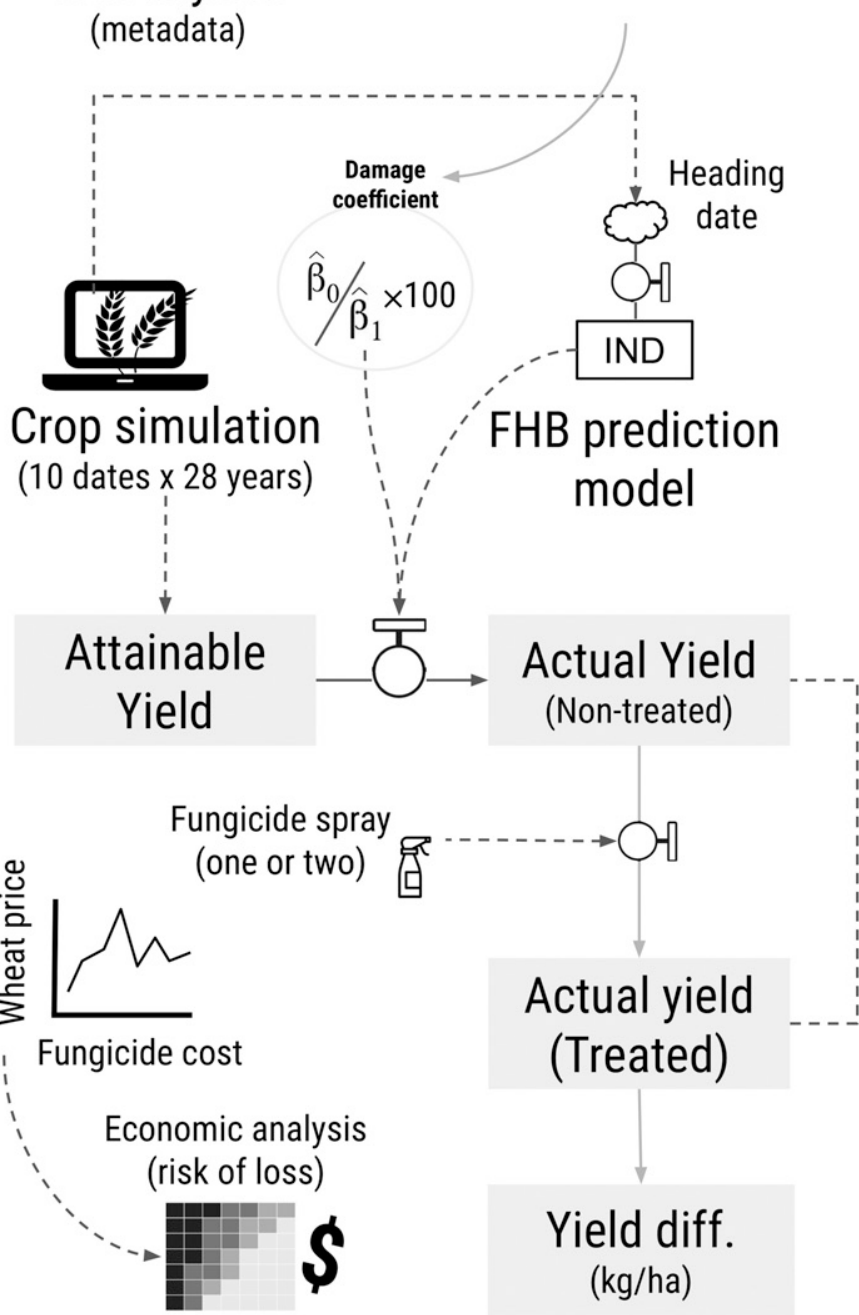

Fig. 1. Simplified diagram depicting the steps to model yield losses caused by Fusarium head blight in spring wheat in Brazil and assess the economic impact of fungicide application for preventing the losses. regression model (Del Ponte et al. 2005). The approach was similar to a previous study that simulated FHB index (30 planting dates after 1 June) for a longer (50-year) dataset (Del Ponte et al. 2009). The attainable yields predicted by the crop model were penalized by the respective $D c$, depending on the value of attainable yield, using the predicted value FHB index for each experiment. For example, for the sowing date of 6 June 1990, simulated yield and FHB severity were $3,645.38 \mathrm{~kg} \mathrm{ha}^{-1}$ and $19.5 \%$, respectively. For this situation, using the $D c$ for high yield, FHB reduced yield by $20.5 \%$ or an absolute reduction of $747.17 \mathrm{~kg} \mathrm{ha}^{-1}$.

To test for significance of the trends in yield loss predictions in the time series, as well as to test the effect of two sowing periods (sowing dates before or after 15 June), a generalized additive model (GAM) (Wood 2017) was fitted to the data using the gam function of the $m g c v$ R package (Wood 2017). The smooth terms estimated for each sowing period were compared at $5 \%$ significance.

Risk analysis and fungicide profitability. We were also interested in evaluating and comparing trends of fungicide profitability over the decades, especially before and after FHB resurgence. This analysis was conducted in several steps, with the values of the probability of not offsetting the costs of the fungicide sprays being obtained through a simulation. First, we used available meta-analytic estimates, both the mean and the uncertainty values, of control efficacy $(C)$ for one or two sprays tebuconazole fungicide used in FHB management in Brazil (Machado et al. 2017). We assumed that $C$ follows a uniform distribution given by:

$$
C_{i j}=\operatorname{Uniform}(a, b)_{i j}
$$

where $i$ is the planting date and $j$ is the year, totaling 280 simulations of control efficacy (10 planting dates in June) for one $(1 \times)$ and two (2x) fungicide applications; $a$ and $b$ represent the lower $\left(C I_{L}\right)$ and upper $\left(C I_{U}\right)$ limits of the $95 \%$ confidence interval $(C I)$ around $C$. The CIs ranged from 46.9 to $67.5 \%$ for one $(1 \times)$ fungicide application and from 44.3 and $60.7 \%$ for two $(2 \times)$ fungicide applications (Machado et al. 2017).

A simulated $C$ value was then used to update both the FHB index and yield in the fungicide-protected $\left(\right.$ Yield $\left._{f}\right)$ plots. The mean yield difference $(D)$ for one spray was given by the difference in yield between fungicide-protected $\left(\right.$ Yield $_{f}$ ) and no-fungicide (Yield ${ }_{n f}$ ) plots (Machado et al. 2017; Madden et al. 2016). The $D$ from using two sprays was calculated by adding a simulated (normally distributed) mean yield gain from using a second spray of tebuconazole, as determined in the previous meta-analysis study (Machado et al. 2017) (equation 2):

$$
D_{i j}=\left(\text { Yield }_{f(i j)}-\text { Yield }_{n f(i j)}\right)+N\left(\mu, \sigma^{2}\right)_{i j}
$$

where $i$ is the planting date and $j$ is the year; $\mu$ is $101.6 \mathrm{~kg} \mathrm{ha}^{-1}$, representing the mean yield difference between the $1 \times$ and $2 x$ fungicide applications (Machado et al. 2017); and $\sigma$ is 43.8, which was calculated based on the mean of the lower $\left(C I_{L}\right)$ and upper $\left(C I_{U}\right)$ limits of the $95 \% C I$ around $D$ for one spray. Finally, the betweenyear variance $\sigma_{\text {year }}^{2}$ was estimated based on the 10 values of $D$ within each year, or across planting dates.

The estimates of $D$ and $\sigma_{\text {year }}^{2}$ were used to calculate the risk (probability) of not offsetting fungicide application cost $\left(P_{l o s s}\right)$, taking both fungicide application $\operatorname{cost}\left(F_{c}=\right.$ fungicide plus application costs) and the average wheat price $\left(W_{p}\right)$ by year. This probability is the cumulative standard-normal function given by:

$$
P_{\text {loss }}=1-\Phi\left(\frac{D-\frac{F_{c}}{W_{p}}}{\sqrt{\sigma_{\text {year }}^{2}}}\right)
$$


where $\Phi$ is the cumulative standard-normal function (Machado et al. 2017; Paul et al. 2011).

Five $F_{c}$ values ( $\$ 10$ to $\$ 30 \mathrm{ha}^{-1}$ ) and five $W_{p}$ values $(\$ 125$ to $\$ 225$ $\mathrm{ha}^{-1}$ ) were created to simulate 25 benefit-cost scenarios. The minimum and maximum $F_{c}$ values were defined based on previous studies in the region (Machado et al. 2017; Panisson et al. 2003; Reis et al. 1996). Likewise, the range of prices for $W_{p}$ was defined based on published statistics for southern Brazil (Brum and Heck 2005; CEPEA 2018). A summary value of $P_{\text {loss }}$ was calculated for each year by taking the mean (and respective $95 \% C I$ ) of all combinations of benefit-cost scenarios and planting dates $(n=250)$. Line and time series plots were created to visualize the magnitude of the
A

\section{Baseline yield: High}

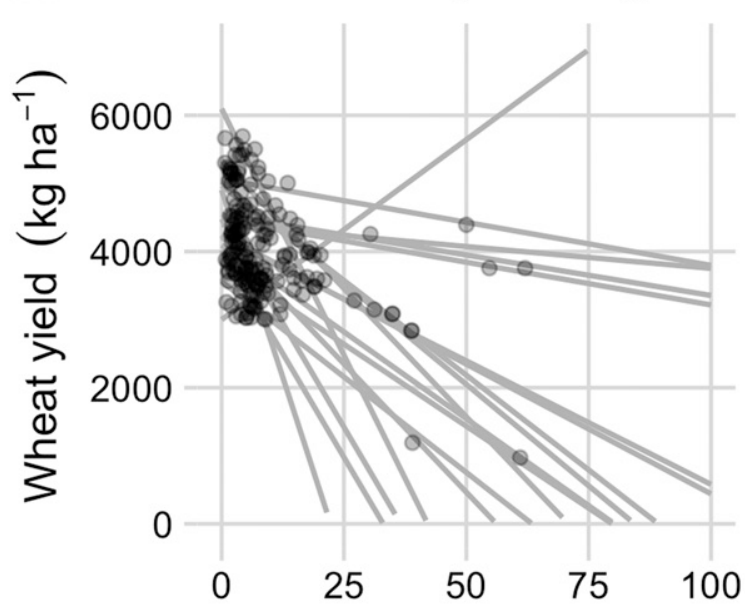

C

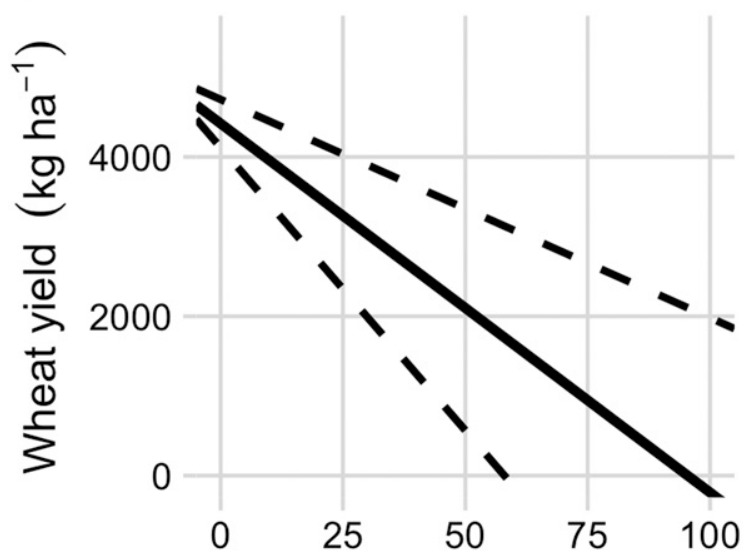

E

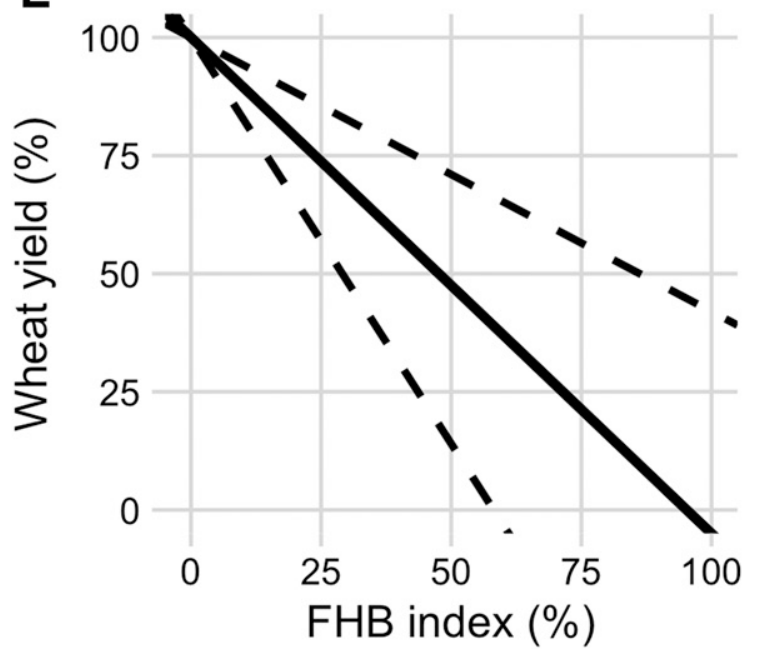

B

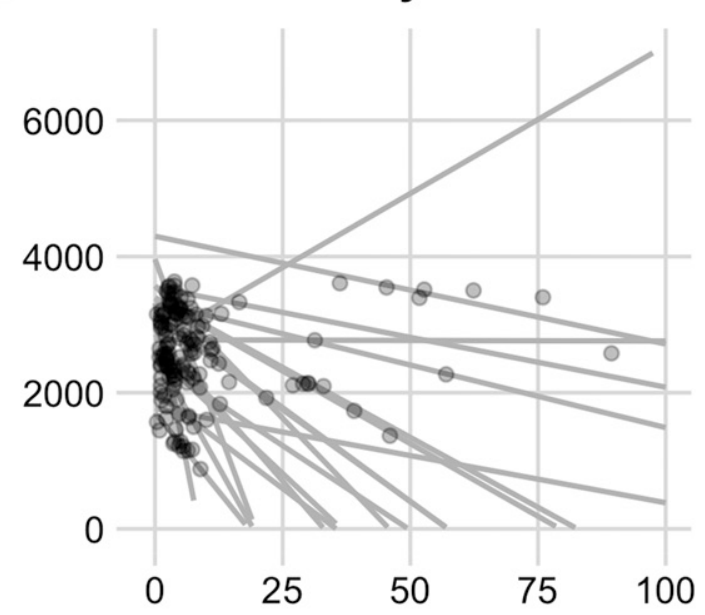

D

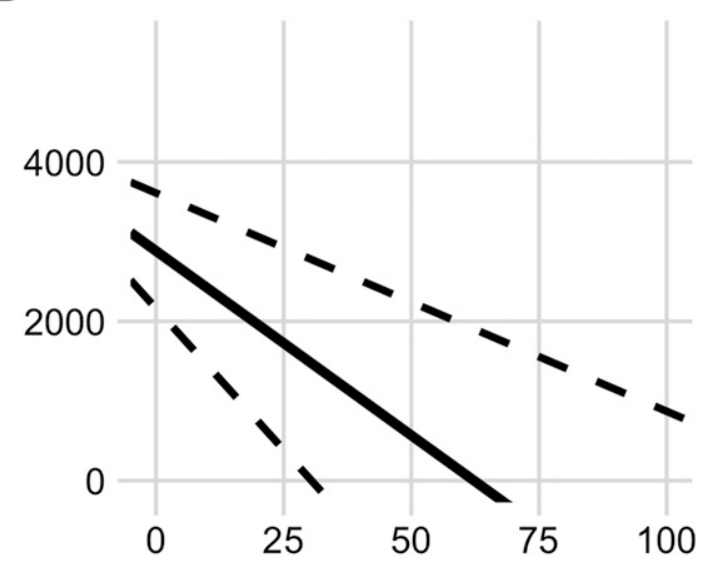

$\mathbf{F}$

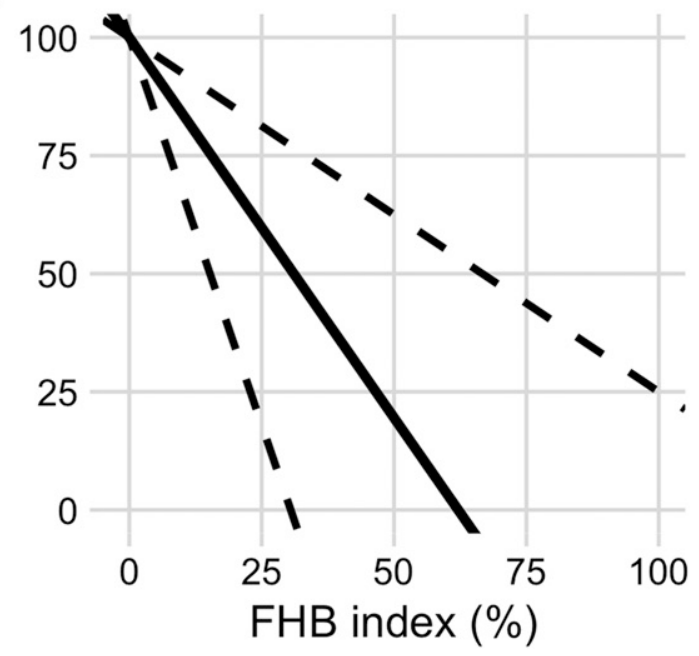

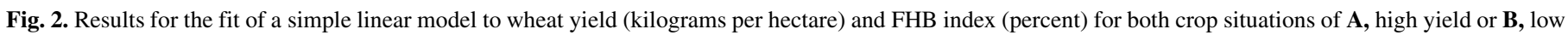

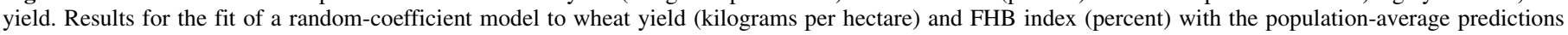

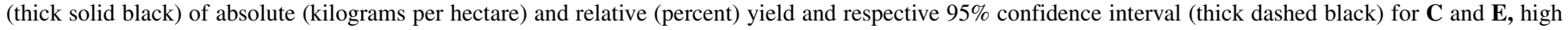
yield or $\mathbf{D}$ and $\mathbf{F}$, low yield. 
probabilities for each benefit-cost scenario as well as probabilities over time considering one and two sprays. A simplified diagram depicting the steps of our modeling approach is presented in Figure 1.

Data availability and reproducibility. All data gathered for this study as well as the fully annotated computational codes, prepared in R Markdown, were organized as a research compendium publicly available at https://osf.io/3h9ye/. A website was generated to facilitate visualization of the commented scripts (https://emdelponte.github.io/paper-FHB-yield-loss/). All analyses were conducted in R statistical software (R Core Team 2013).

\section{RESULTS}

Yield-severity relationship. Simple linear regression model. Across all studies, FHB index in the nontreated plots ranged from 5 to $89.3 \%$ (mean $=23.6 \%)$. In 19 trials $(51.3 \%)$, FHB index was $>10 \%$, which is considered a threshold for epidemics of concern (Shah et al. 2013). Maximum yield ranged from 1,460 to 5,692 kg ha $^{-1}\left(\right.$ mean $\left.=3,676 \mathrm{~kg} \mathrm{ha}^{-1}\right)$.

Intercepts and slopes varied considerably within each baseline yield category. For $Y l$, intercepts ranged from 1,708 to $4,299 \mathrm{~kg} \mathrm{ha}^{-1}$, with an overall mean of $2,977 \mathrm{~kg} \mathrm{ha}^{-1}$, and slopes ranged from 43.5 to $-381.9 \mathrm{~kg}$ $\mathrm{ha}^{-1}$, with overall mean of $-71.8 \mathrm{~kg} \mathrm{ha}^{-1}$ (Fig. 2A). For the $Y \mathrm{~h}$ crop situation, intercepts ranged from 3,000 to $6,097 \mathrm{~kg} \mathrm{ha}^{-1}$, with an overall mean of 4,473 $\mathrm{kg} \mathrm{ha}^{-1}$ (Supplementary Table S2), and slopes ranged from 52.9 to $-220.2 \mathrm{~kg} \mathrm{ha}^{-1}$, with overall mean of $-60.9 \mathrm{~kg} \mathrm{ha}^{-1}$ (Fig. $2 \mathrm{~A})$. All but two slopes $\left(\beta_{1}\right)$ were negative, one in each yield group, indicating that yield generally decreased as FHB index increased.

Random coefficients model. The multilevel model that considers the random effect of individual trials on both the intercept and slope provided a better fit to the data, compared with slope- or intercept-only models (data not shown), across the 37 trials. Mixed model-derived intercept and slope values varied among individual studies (Supplementary Table S2). The study-specific intercepts $\left(\hat{\beta}_{0}\right)$ ranged from 1,620 to $5,786 \mathrm{~kg} \mathrm{ha}^{-1}\left(\mathrm{ID}=2,470.6 \mathrm{~kg} \mathrm{ha}^{-1}\right)$ and study-specific slope $\left(\hat{\beta}_{1}\right)$ values ranged from 4.5 to $112.5 \mathrm{~kg} \mathrm{ha}^{-1}$ $\%^{-1}($ ID $=76.8)$. The estimates of population-average of the intercept and slope were $\hat{\beta}_{0}=3,645.3 \mathrm{~kg} \mathrm{ha}^{-1}$ (standard error [SE] $=164.6)$ and $\hat{\beta}_{1}=49.1 \mathrm{~kg} \mathrm{ha}^{-1} \%^{-1}(\mathrm{SE}=7.4)$, respectively. Both parameters were statistically different from $0(P<0.001)$.

The best model, defined based on a likelihood ratio test $(P<$ 0.001 ) and lowest Akaike information criterion (4,595), included baseline yield as a covariate. A Wald-type test showed that effect of baseline yield on the slope $(\zeta)$ did not differ from $0(P>0.80)$, suggesting that the slope was not affected by baseline yield. However, as expected, effect of baseline yield on the intercept $(\xi)$ differed from zero $(P<0.01)$. The study-specific parameters estimated were $\hat{\beta}_{0}=4,419.5 \mathrm{~kg} \mathrm{ha}^{-1}(\mathrm{SE}=148.3), \hat{\beta}_{1}=46.3 \mathrm{~kg} \mathrm{ha}^{-1}$ $\%^{-1}(\mathrm{SE}=9.6)$, and $\hat{\xi}_{\text {low }}=-1,535.9 \mathrm{~kg} \mathrm{ha}^{-1}(\mathrm{SE}=209.4)$. Population-average predictions were then split into two regression equations to account for the effects of the covariate on the intercept. In addition, $\xi$ was a dummy variable of value of zero for high yield (i.e., $\hat{\xi}_{\text {high }}=0$ ). Because of the negative value for $\hat{\xi}_{\text {low }}$, wheat yield was, on average, $1,535.9 \mathrm{~kg} \mathrm{ha}^{-1}$ lower than in the high-yield trials. The population-average predictions of yield are given by:

$$
\text { Yield }=\hat{\beta}_{0}+\widehat{\hat{\xi}}-\hat{\beta}_{1} * F H B_{\text {index }}
$$

which gives the following equations for high and low wheat yield:

$$
\begin{gathered}
Y h=4,419.5+0-46.3 \times F H B_{\text {index }} \\
Y l=4,419.5+(-1,535.9)-46.3 \times F H B_{\text {index }}
\end{gathered}
$$

The population-average (and respective $95 \% C I$ ) predictions for the inclusion of the covariate baseline yield in the model are shown in Figure 2B. Because the estimated slope did not differ between the lowand high-yield class, a reduction of $1,000 \mathrm{~kg} \mathrm{ha}^{-1}$ would occur at an FHB index of $21.6 \%$ for both yield classes. The calculated $D c$ for highyield and low-yield baselines were $1.05 \%^{-1}$ and $1.60 \% \%^{-1}$, respectively.

Model-predicted yield losses. All simulated values of attainable yields were greater than our threshold used to define the category of baseline yield $\left(3,631 \mathrm{~kg} \mathrm{ha}^{-1}\right)$. Hence, we used the $D c$ for high-yield conditions $\left(D c_{h}=1.05 \%\right.$ percentage point $\left.{ }^{-1}\right)$ to obtain actual yields (FHB-induced loss). Yield losses varied both intra- and interannually but especially when comparing the decadal periods. Prior to 1990, yield losses ranged from 1.0 to $12.6 \%$ (mean = $5.8 \%$ ). For the two subsequent periods, 1990 to 1999 and 2000 to 2007 , losses ranged from 3.1 to $22.6 \%($ mean $=10.3 \%)$ and from 3.2 to $25.8 \%$ (mean $=10.2 \%)$, respectively $($ Fig. $3 \mathrm{~A})$. A significant upward trend in yield loss was detected in the time series $(P<0.01)$. The differences between the smooth terms of the model fitted using two planting date periods as covariates, representing the first and second half of June, were not significant $(P>0.05)$ although,
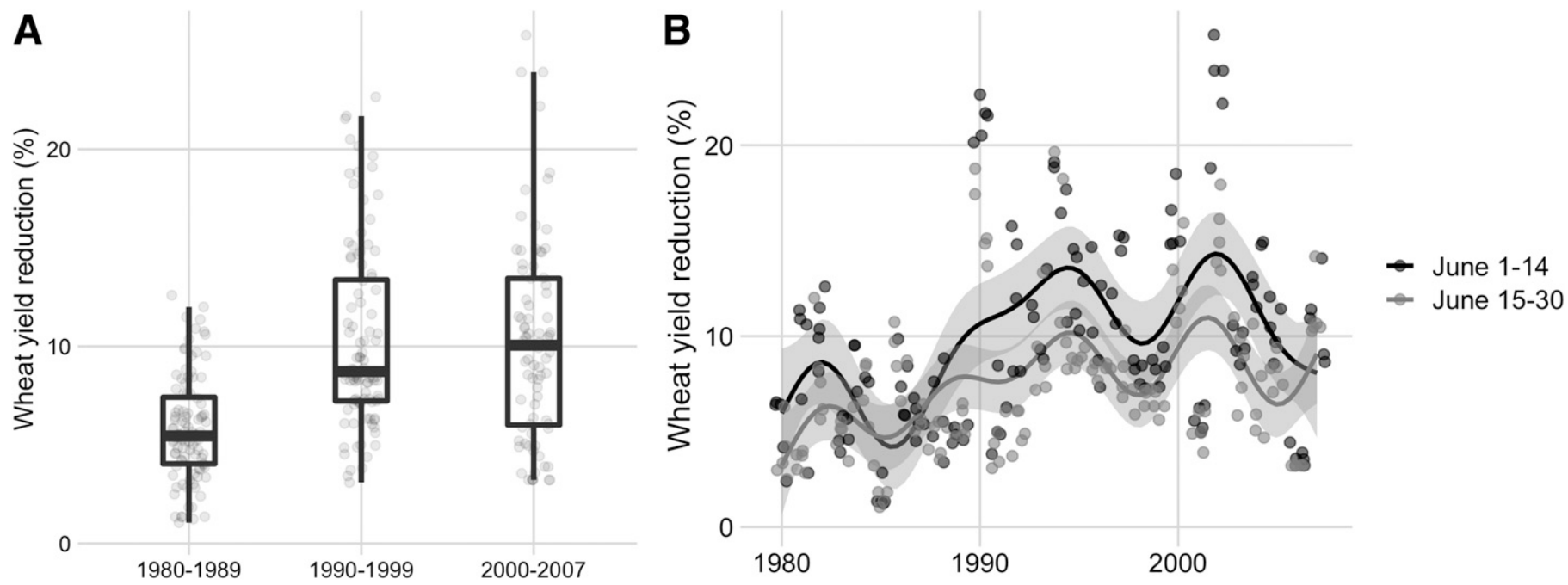

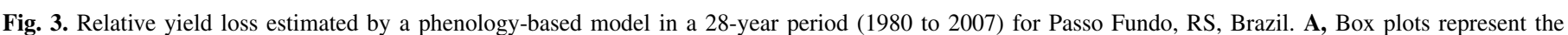

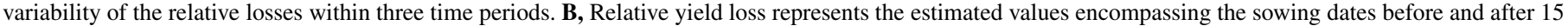
June, with the fitted smoothing lines of the generalized additive model for both sowing periods. 
numerically, the reductions appeared higher for the first plantings of June (Fig. 3B).

Fungicide profitability. The probability of loss $\left(P_{\text {loss }}\right)$ was generally greater prior to 1990 compared with the other years (Fig. 4A). For this period, $P_{\text {loss }}>75$ and $50 \%$ were calculated for 8 and 14 benefit-cost scenarios, respectively. After 1989, these same probabilities were reduced to only one and six scenarios (Fig. 4). The number of sprays appeared to have little effect on $P_{\text {loss }}$. For example, for an average benefit-cost scenario $\left(W_{p}=\right.$ U.S. $\$ 175 /$ ton and $F_{c}=$ U.S.\$20/ha), $P_{\text {loss }}$ was 59,26 , and $35 \%$ for 1980 to 1989 , 1990 to 1999 , and 2000 to 2007, respectively. When using two sprays, the $P_{\text {loss }}$ values for the same scenarios were 59,33 , and $34 \%$. The lack of a clear benefit from two sprays compared with one spray is apparent in the series of the yearly mean and uncertainty of $P_{\text {loss }}$ (Fig. 5). Prior to 1990, the mean $P_{\text {loss }}$ was $>50 \%$ in 7 of 10 years, decreasing considerably afterward. After $1989, P_{\text {loss }}>60 \%$ was estimated for only 3 of 18 years. For this same period, $P_{\text {loss }}$ was mostly higher for two sprays compared with one.

\section{DISCUSSION}

Our modeling of yield losses confirms that FHB is an important yield-limiting disease of spring wheat in the subtropics, especially after the 1990s, when damaging epidemics became more frequent (Casa et al. 2004; Del Ponte et al. 2009; Panisson et al. 2003; Spolti et al. 2015). This study also provided numerical estimates of yield loss trends due to FHB in a temporal series of 28 years by linking the meta-analytical estimate parameters to a crop and a disease model that estimate yield and disease, respectively.

Our meta-analytic estimate of yield (population-average intercept) was similar to the estimates for the same wheat type (spring) in the United States using a similar statistical approach (Madden and Paul 2009). The variance in the parameter estimates of meta-regression models may be reduced by inclusion of additional covariates in the model (Madden and Paul 2009). Although baseline yield did not affect the population-average slope in our study, intercept values differed between trials representing a low or a high baseline yield, which was not an unexpected result. In fact, a similar pattern was found in the U.S. study (Madden and Paul 2009), where population-average slopes did not differ between spring and winter wheat, which typically represent low- and high-yielding wheat, respectively. Given that intercept values varied among the studies, the magnitude of the $D c$, which depends on both coefficients, differed between baseline yields but was rather similar between countries for an equivalent baseline yield. For example, for our high-yielding spring wheat, the $D c$ calculated in our study $\left(1.05 \%^{-1}\right)$ was very close to an overall (unconditioned) $D c$ calculated for spring wheat in the United States $\left(0.99 \%^{-1}\right)$ (Madden and Paul 2009). In a further U.S. study using data for soft red winter wheat, the $D c$ due to FHB was slightly greater $\left(1.17 \%^{-1}\right)$ and neither wheat cultivar nor the presence of the foliar disease Stagonospora leaf blotch significantly affected the slopes (Salgado et al. 2015).
A

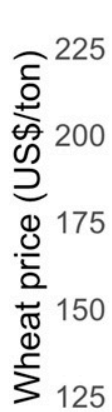

125

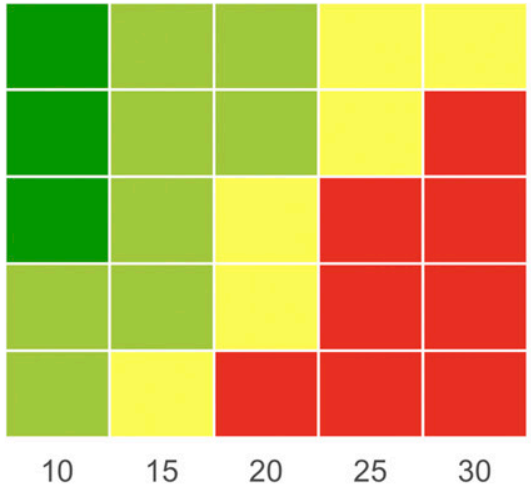

1980-1989

B

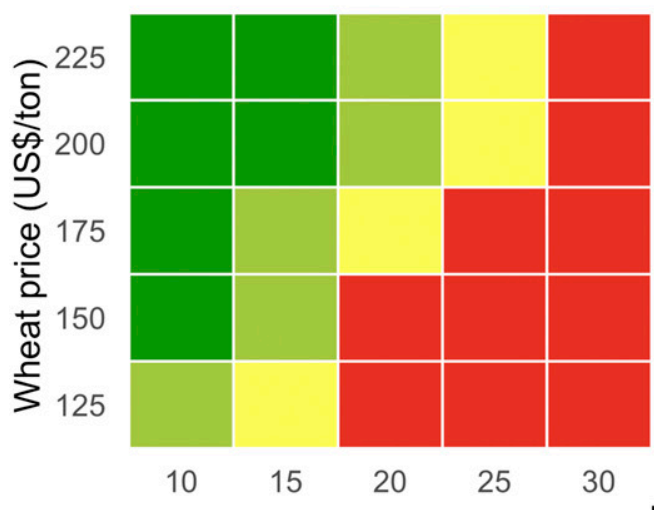

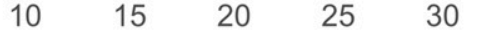

1990-1999

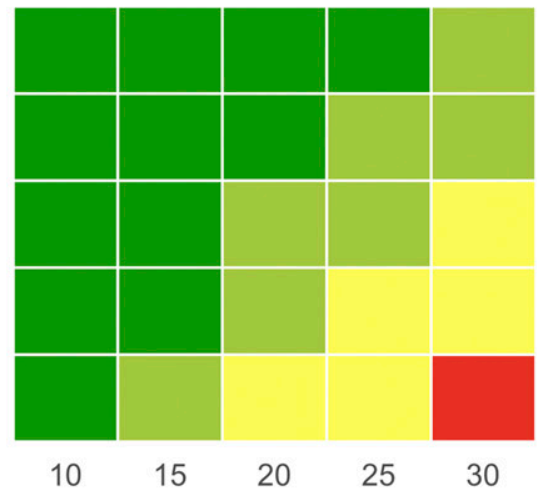

1990-1999

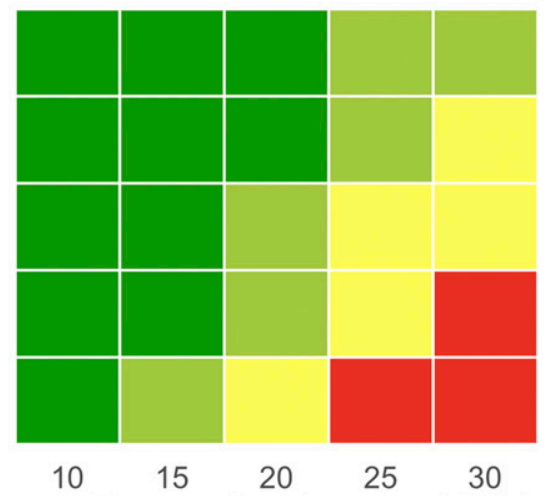

Fungicide + application cost (US\$/ha)
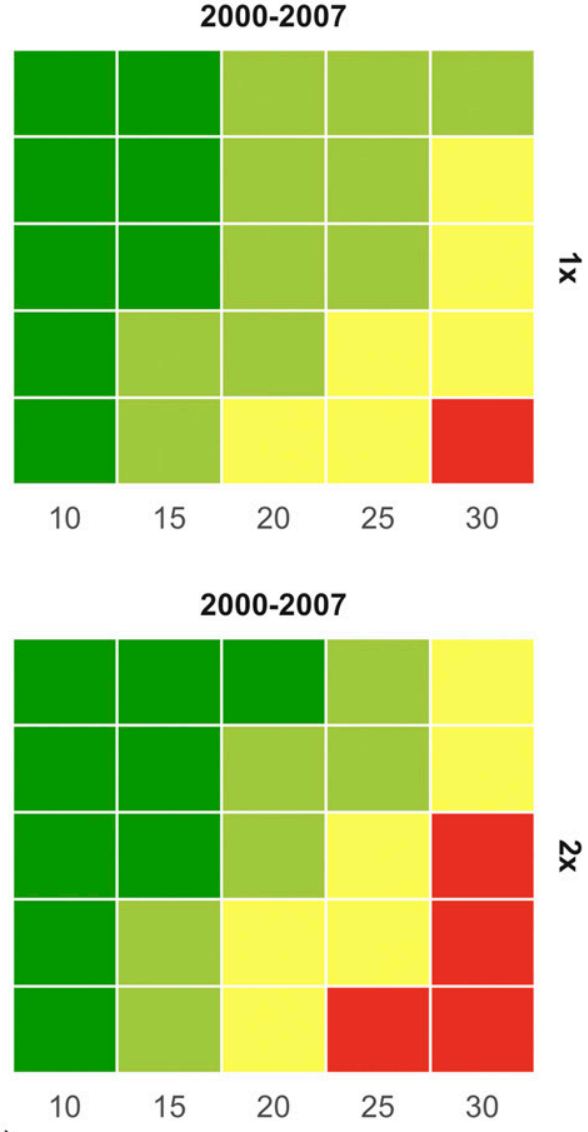

Probability of not-offsetting costs

$0 \% \leq p<25 \%$

$25 \% \leq p<50 \%$

$50 \% \leq p<75 \%$

$75 \% \leq p<100 \%$

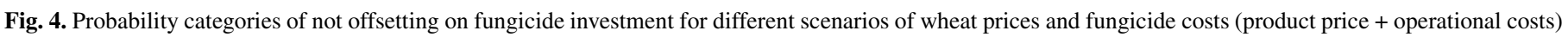

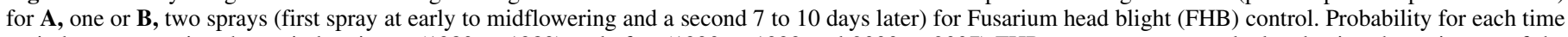

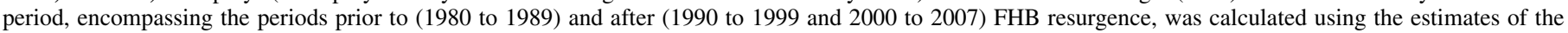

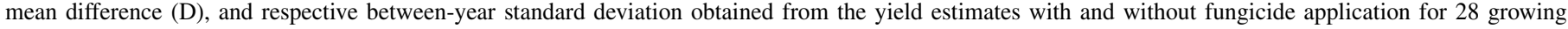
seasons in Brazil. 
The increased $D c$ for subtropical spring wheat in the low-yielding situation $\left(1.60 \%^{-1}\right)$ may be due to the additional effect of unobserved biotic and abiotic stresses that weaken the plant and its defenses against FHB (Al-Khatib and Paulsen 1999; Asseng et al. 2015; Buck et al. 2007; Sharma et al. 2007). In addition, given that we used data from fungicide trials, we cannot rule out the potential effect of fungicides, especially demethylation inhibitor + quinone outside inhibitor mixtures applied during flowering, that control flag-leaf diseases such as tan spot in Brazil. This can affect the $D c$ due to reduction of the impact of foliar disease, thus protecting yield (Blandino et al. 2006, 2011; Wegulo et al. 2011).

Using a model-based approach that linked disease and attainable yield predictions with actual weather information as an input for each model and estimating disease-induced losses based on the $D c$, yield loss trends were quantified at magnitudes that matched earlier literature reports. For example, a quantitative review of yield losses, measured using a destructive sampling approach in fungicide trials spanning 21 years (1984 to 2010) in southern Brazil, reported that average losses due to FHB shifted from 5.4\% during the period 1984 to 1994 to $21.6 \%$ for the period 2000 to 2010 (Reis and Carmona 2013; Reis et al. 1996). Our simulations confirmed this shift by showing that FHB changed from a secondary disease to an economically damaging disease of wheat after the 1990s. Several reasons explain the reemergence of FHB worldwide, including the wider adoption of conservation tillage practices and increase of wheat-corn rotations, which have been proposed as important risk factors (Dill-Macky and Jones 2000; McMullen et al. 1997; Schaafsma et al. 2001). Although cultural practices aimed at reducing local inoculum are recommended in those studies, current evidence supports the claim that potential effects of local residue management may be overshadowed by other risk factors in Brazil that include (i) overwintering of several grasses that harbor the pathogen (Reis 1990), (ii) the presence of airborne inoculum throughout the year (Fernandes 1997; Reis 1988), and (iii) noninfluence of the presence of within-field maize residues on FHB risk (Spolti et al. 2015). Collectively, results from our simulations, which are based only on seasonal weather and do not take into account changes in agronomic practices (that promote inoculum build-up), confirm that the reemergence of FHB in Brazil has been more likely due to variation in seasonal weather patterns (Del Ponte et al. 2009) rather than cultural practices (Fernandes 1997). The information is critical for breeders, who should intensify efforts to incorporate genetic resistance, which has proven more effective to control the disease when combined with fungicides, a practice that has been widely adopted not only to protect yield but mainly to reduce mycotoxin contamination (McMullen et al. 2012; Wegulo et al. 2015).

Prior to the early 1990s, the profitability of a single fungicide spray during flowering for FHB control was questioned due the sporadic nature and mostly mild FHB epidemics in the preceding decades (Picinini and Fernandes 1998; Reis et al. 1996). However, accurate yield loss estimates, using a destructive sampling approach during the early 2000s, contradicted the previous recommendation and showed economic benefits from using one fungicide spray at full flowering (Panisson et al. 2003). Our model-based estimates of yield losses and fungicide profitability showed that the risk of not offsetting a single fungicide spray was predominantly high prior to the resurgence (pre-1990s), as shown by the low frequency of more profitable conditions, which is in agreement with current recommendations for the period (Reis et al. 1996). The profitability tended to increase in general after the 1990s, when a single fungicide spray (but not often two sprays) was more likely to pay off. Caution is needed in interpretation because, due to a current lack of knowledge, we are not taking into account the effect of fungicide sprays on other traits affected by FHB such as test weight and mycotoxin content, which downgrade grain value (Salgado et al. 2014, 2015).

We found that trends in yield loss were not affected by planting period, although it is expected that there may be annual variation and reports of increasing risk of FHB for later planting dates (after 15 June) compared with prior dates (Lima et al. 2005, 2006). Therefore, it is difficult to ascertain any general recommendation on planting dates for managing FHB, though it is important to mention that our disease model does not take into account an increase in airborne inoculum levels, which tend to peak later in the season (Del Ponte et al. 2005). Given the dependence of FHB epidemics on

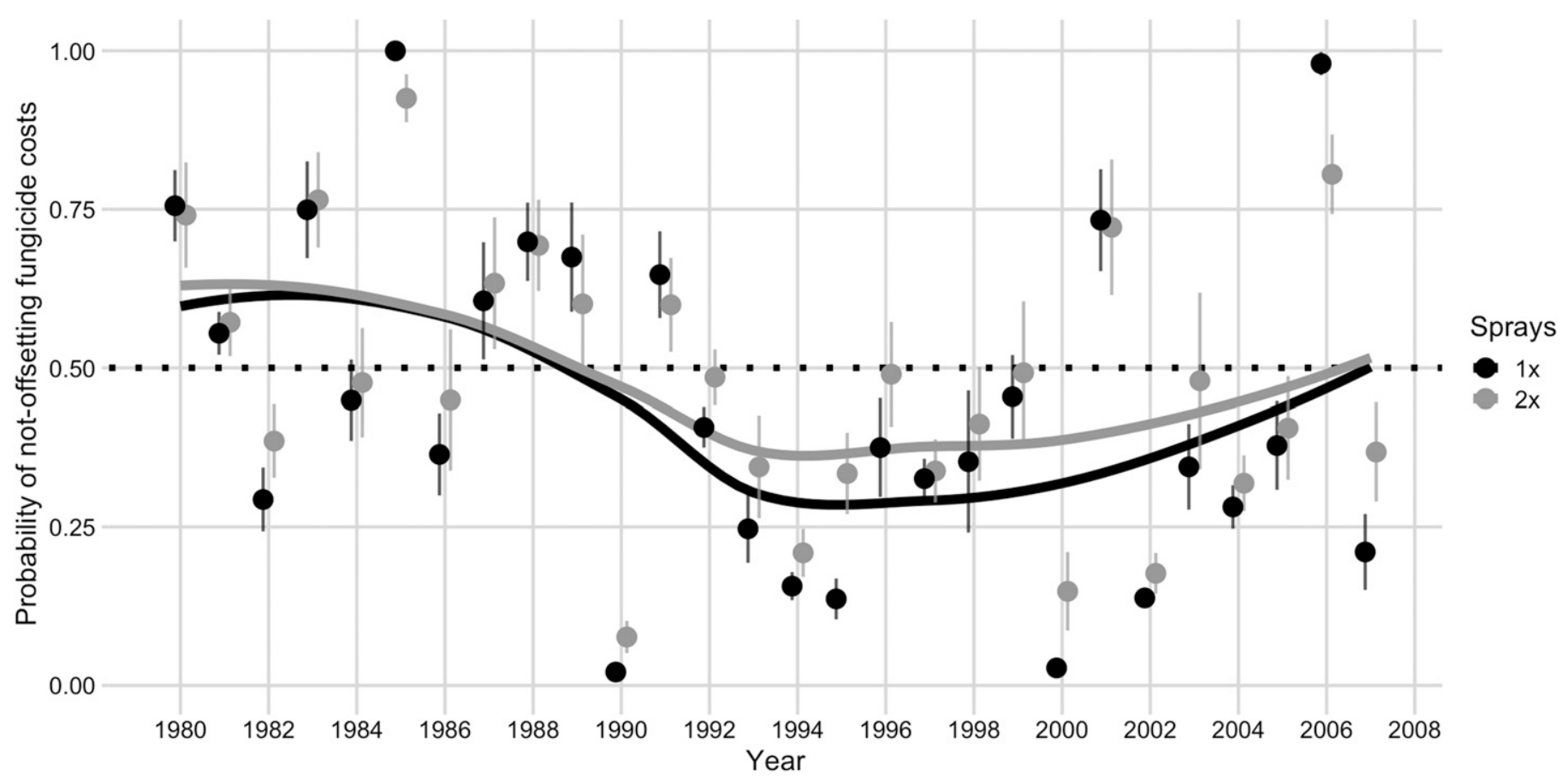

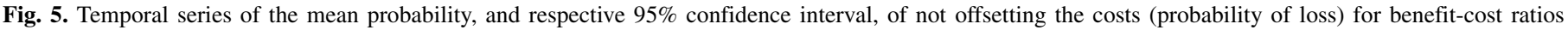
(wheat price/fungicide cost in U.S. dollars) ranging from 5 to 15. Probabilities were calculated for both one and two fungicide applications. 
weather conditions during a relatively short period (flowering) (Del Ponte et al. 2005), diversification of planting dates has been proposed as a way to minimize risk through an escape mechanism (Reis and Carmona 2013). Indeed, our simulations showed significant within-year variations in yield losses, varying in magnitude across the years.

The framework developed in this study proved useful to quantify the impact and highlight the importance of FHB as a yield-limiting disease. The model parameters and predicted responses matched quite well with results from other countries with regards the impact of the disease on yield, as well as with historical information on the impact of FHB in Brazil. As long as information on the impact of FHB on quality parameters that downgrade wheat and the effectiveness of control methods targeting them are available for the region, further economic analysis may provide even more useful estimates. However, considering only losses in yield, our simulations confirm that one spray of tebuconazole is generally profitable in the current scenario, except during years that are not conducive for FHB, which are less likely in the case of Brazil, as shown by our FHB predictions. Although it may be argued that the use of chemicals that are more effective than tebuconazole may provide better response in yield, they are generally more expensive and, thus, do not dramatically affect profitability. Under the simulated scenarios that used the available meta-analytic estimate for the mean increment in yield from using a second spray of tebuconazole, we found that the profitability was not affected. Situations in which a second fungicide spray is worth the cost should be better explored by considering different chemicals and cultivar resistance and their effect on parameters that downgrade grain quality such as test weight and mycotoxin contamination.

\section{ACKNOWLEDGMENTS}

We thank A. Lazzaretti and J. M. Fernandes for providing simulated yield data from the AgroWEB system.

\section{LITERATURE CITED}

Al-Khatib, K., and Paulsen, G. M. 1999. High-temperature effects on photosynthetic processes in temperate and tropical cereals. Crop Sci. 39:119-125.

Asseng, S., Ewert, F., Martre, P., Rötter, R. P., Lobell, D. B., Cammarano, D., Kimball, B. A., Ottman, M. J., Wall, G. W., White, J. W., Reynolds, M. P., Alderman, P. D., Prasad, P. V. V., Aggarwal, P. K., Anothai, J., Basso, B., Biernath, C., Challinor, A. J., De Sanctis, G., Doltra, J., Fereres, E., Garcia-Vila, M., Gayler, S., Hoogenboom, G., Hunt, L. A., Izaurralde, R. C., Jabloun, M., Jones, C. D., Kersebaum, K. C., Koehler, A.-K., Müller, C., Naresh Kumar, S., Nendel, C., O’Leary, G., Olesen, J. E., Palosuo, T., Priesack, E., Rezaei, E. E., Ruane, A. C., Semenov, M. A., Shcherbak, I., Stöckle, C., Stratonovitch, P., Streck, T., Supit, I., Tao, F., Thorburn, P. J., Waha, K., Wang, E., Wallach, D., Wolf, J., Zhao, Z., and Zhu, Y. 2015. Rising temperatures reduce global wheat production. Nat. Clim. Chang. 5:143-147.

Blandino, M., Minelli, L., and Reyneri, A. 2006. Strategies for the chemical control of Fusarium head blight: Effect on yield, alveographic parameters and deoxynivalenol contamination in winter wheat grain. Eur. J. Agron. 25: 193-201.

Blandino, M., Pascale, M., Haidukowski, M., and Reyneri, A. 2011. Influence of agronomic conditions on the efficacy of different fungicides applied to wheat at heading: Effect on flag leaf senescence, Fusarium head blight attack, grain yield and deoxynivalenol contamination. Ital. J. Agron. 6: 204-211.

Brum, A. L., and Heck, C. R. 2005. A economia do trigo no Rio Grande do Sul: Breve histórico do cereal na economia do estado. Rev. Analg. 16: 29-44.

Buck, H. T., Nisi, J. E., and Salomón, N., eds. 2007. Wheat Production in Stressed Environments. Springer, Dordrecht, The Netherlands.

Casa, R. T., Reis, E. M., Blum, M. M. C., Bogo, A., Scheer, O., and Zanata, T. 2004. Danos causados pela infecção de Gibberella zeae em trigo. Fitopatol. Bras. 29:289-293.

CEPEA. 2018. Preço médio do trigo CEPEA/ESALQ. Centro de Estudos Avançados em Economia Aplicada, Piracicaba, SP, Brazil. https:// www.cepea.esalq.usp.br/br/indicador/trigo.aspx
CONAB. 2018. Acompanhamento de safra brasileira de grão. Companhia Nacional de Abastecimento, Brasília, DF, Brazil. https://www.conab.gov.br/ info-agro/safras

Dalla Lana, F., Ziegelmann, P. K., and Maia, A. de H. N., Godoy, C. V., and Del Ponte, E. M. 2015. Meta-analysis of the relationship between crop yield and soybean rust severity. Phytopathology 105:307-315.

Del Ponte, E. M., Fernandes, J. M. C., and Pavan, W. 2005. A risk infection simulation model for fusarium head blight of wheat. Fitopatol. Bras. 30: 634-642.

Del Ponte, E. M., Fernandes, J. M. C., Pavan, W., and Baethgen, W. E. 2009. A model-based assessment of the impacts of climate variability on Fusarium head blight seasonal risk in southern Brazil. J. Phytopathol. 157:675-681.

Del Ponte, E. M., Spolti, P., Ward, T. J., Gomes, L. B., Nicolli, C. P., Kuhnem, P. R., Silva, C. N., and Tessmann, D. J. 2015. Regional and field-specific factors affect the composition of Fusarium head blight pathogens in subtropical no-till wheat agroecosystem of Brazil. Phytopathology 105: 246-254.

Dill-Macky, R., and Jones, R. K. 2000. The effect of previous crop residues and tillage on Fusarium head blight of wheat. Plant Dis. 84:71-76.

Edwards, S. G., and Godley, N. P. 2010. Reduction of Fusarium head blight and deoxynivalenol in wheat with early fungicide applications of prothioconazole. Food Addit. Contam. Part A. 27:629-635.

Edwards Molina, J. P., Paul, P. A., Amorim, L., da Silva, L. H. C. P., Siqueri, F. V., Borges, E. P., Campos, H. D., Nunes, J., Jr., Meyer, M. C., Martins, M. C., Balardin, R. S., Carlin, V. J., Grigolli, J. F. J., Belufi, L. M. de R., and Godoy, C. V. 2018. Meta-analysis of fungicide efficacy on soybean target spot and cost-benefit assessment. Plant Pathol. 68:94-106.

Fernandes, J. M. C. 1997. As doenças das plantas e o sistema de plantio direto. Rev. An. Patol. Plantas 5:317-352.

Goswami, R. S., and Kistler, H. C. 2004. Heading for disaster: Fusarium graminearum on cereal crops. Mol. Plant Pathol. 5:515-525.

Landschoot, S., Audenaert, K., Waegeman, W., De Baets, B., and Haesaert, G. 2013. Influence of maize-wheat rotation systems on Fusarium head blight infection and deoxynivalenol content in wheat under low versus high disease pressure. Crop Prot. 52:14-21.

Lazzaretti, A. T., Fernandes, J. M., and Pavan, W. 2015. Calibração do cropsim-wheat para simulação do desenvolvimento e rendimento de grão de trigo no Sul do Brasil. Rev. Bras. Ciênc. Agrár. [Braz. J. Agric. Sci.] 10: 356-364.

Lehner, M. S., Pethybridge, S. J., Meyer, M. C., and Del Ponte, E. M. 2017. Meta-analytic modelling of the incidence-yield and incidence-sclerotial production relationships in soybean white mould epidemics. Plant Pathol. 66:460-468.

Lima, M. I. P. M., Só e Silva, M., Caierão, E., Schereen, P. L., Del Duca, I. J. A., and Pires, J. L. 2006. Avaliação de giberela em genótipos de trigo do ensaio estadual de cultivares, na região de Passo Fundo, em 2005. Documento online 66. Embrapa Trigo, Passo Fundo, RS, Brazil. http:// www.cnpt.embrapa.br/biblio/do/p_do66.htm

Lima, M. I. P. M., Só e Silva, M., Schereen, P. L., Del Duca, I. J. A., Pires, J. L., and Nascimento, A., Jr. 2005. Avaliação de giberela em genótipos de trigo do ensaio estadual de cultivares, na região de Passo Fundo, em 2004. Documento online 52. Embrapa Trigo, Passo Fundo, RS, Brazil. http:// www.cnpt.embrapa.br/biblio/do/p_do52.htm

Machado, F. J., Santana, F. M., Lau, D., and Del Ponte, E. M. 2017. Quantitative review of the effects of triazole and benzimidazole fungicides on Fusarium head blight and wheat yield in Brazil. Plant Dis. 101:1633-1641

Madden, L. V., and Paul, P. A. 2009. Assessing heterogeneity in the relationship between wheat yield and Fusarium head blight intensity using random-coefficient mixed models. Phytopathology 99:850-860.

Madden, L. V., Piepho, H.-P., and Paul, P. A. 2016. Statistical models and methods for network meta-analysis. Phytopathology 106:792-806.

McMullen, M., Bergstrom, G., De Wolf, E., Dill-Macky, R., Hershman, D., Shaner, G., and Van Sanford, D. 2012. A unified effort to fight an enemy of wheat and barley: Fusarium head blight. Plant Dis. 96:1712-1728.

McMullen, M., Jones, R., and Gallenberg, D. 1997. Scab of wheat and barley: A re-emerging disease of devastating impact. Plant Dis. 81:1340-1348.

Moschini, R. C., Martínez, M. I., and Sepulcri, M. G. 2013. Modeling and forecasting systems for Fusarium head blight and deoxynivalenol content in wheat in Argentina. Pages 205-227 in: Fusarium Head Blight in Latin America. T. M. Alconada Magliano and S. N. Chulze, eds. Springer, Dordrecht, The Netherlands.

Panisson, E., Reis, E. M., and Boller, W. 2003. Quantificação de danos causados pela giberela em cereais de inverno, na safra 2000, em Passo Fundo, RS. Fitopatol. Bras. 28:189-192.

Paul, P. A., Lipps, P. E., Hershman, D. E., McMullen, M. P., Draper, M. A., and Madden, L. V. 2007. A quantitative review of tebuconazole effect on Fusarium head blight and deoxynivalenol content in wheat. Phytopathology 97:211-220. 
Paul, P. A., Lipps, P. E., Hershman, D. E., McMullen, M. P., Draper, M. A., and Madden, L. V. 2008. Efficacy of triazole-based fungicides for Fusarium head blight and deoxynivalenol control in wheat: A multivariate metaanalysis. Phytopathology 98:999-1011.

Paul, P. A., Lipps, P. E., and Madden, L. V. 2005. Relationship between visual estimates of Fusarium head blight intensity and deoxynivalenol accumulation in harvested wheat grain: A meta-analysis. Phytopathology 95:1225-1236.

Paul, P. A., Madden, L. V., Bradley, C. A., Robertson, A. E., Munkvold, G. P., Shaner, G., Wise, K. A., Malvick, D. K., Allen, T. W., Grybauskas, A., Vincelli, P., and Esker, P. 2011. Meta-analysis of yield response of hybrid field corn to foliar fungicides in the U.S. Corn Belt. Phytopathology 101:1122-1132.

Picinini, E. C., and Fernandes, J. M. C. 1998. Avaliação de fungicidas no controle de giberela em trigo. Fitopatol. Bras. 23:270.

R Core Team. 2013. R: A Language and Environment for Statistical Computing. R Foundation for Statistical Computing, Vienna, Austria. http:// www.R-project.org/

Reis, E. M. 1988. Quantificação de propágulos de Gibberella zeae no ar através de armadilhas de esporos. Fitopatol. Bras. 13:324-327.

Reis, E. M. 1990. Perithecial formation of Gibberella zeae on senescent stems of grasses under natural conditions. Fitopatol. Bras. 15:52-54.

Reis, E. M., Blum, M. M. C., Casa, R., and Medeiros, C. A. 1996. Grain losses caused by the infection of wheat heads by Gibberella zeae in southern Brazil, from 1984 to 1994. Summa Phytopathol. 22:134-137.

Reis, E. M., and Carmona, M. A. 2013. Integrated disease management of Fusarium head blight. Pages 159-173 in: Fusarium Head Blight in Latin America. T. M. Alconada Magliano and S. N. Chulze, eds. Springer, Dordrecht, The Netherlands.

Salgado, J. D., Madden, L. V., and Paul, P. A. 2014. Efficacy and economics of integrating in-field and harvesting strategies to manage Fusarium head blight of wheat. Plant Dis. 98:1407-1421.

Salgado, J. D., Madden, L. V., and Paul, P. A. 2015. Quantifying the effects of Fusarium head blight on grain yield and test weight in soft red winter wheat. Phytopathology 105:295-306.

Salgado, J. D., Wallhead, M., Madden, L. V., and Paul, P. A. 2011. Grain harvesting strategies to minimize grain quality losses due to Fusarium head blight in wheat. Plant Dis. 95:1448-1457.

Santana, F. M., Lau, D., Aguilera, J. G., Sbalcheiro, C. C., Feksa, H., Floss, L. G., and Guterres, C. W. 2016a. Eficiência de fungicidas para controle de Gibberella zeae em trigo: Resultados dos Ensaios Cooperativos-Safra 2013. Comunicado Técnico 362. Embrapa Trigo, Passo Fundo, RS, Brazil.

Santana, F. M., Lau, D., Cargnin, A., Seixas, C. D. S., Schipanski, C. A., Feksa, H. R., Wesp, C., Blum, M., and Bassoi, M. C. 2014. Eficiência de fungicidas para controle de giberela em trigo: Resultados dos ensaios cooperativos-Safra 2012. Comunicado Técnico 336. Embrapa Trigo, Passo Fundo, RS, Brazil.

Santana, F. M., Lau, D., Maciel, J. L. N., Cargnin, A., Seixas, C. D. S., Bassoi, M. C., Schipanski, C. A., Feksa, H., Casa, R. T., Wesp, C., Navarini, L., and Blum, M. 2012. Eficiência de fungicidas para controle de giberela em trigo: Resultados dos ensaios cooperativos-Safra 2011. Comunicado Técnico 23. Embrapa Trigo, Passo Fundo, RS, Brazil.

Santana, F. M., Lau, D., Sbalcheiro, C. C., Feksa, H., Guterres, C. W., and Venâncio, W. S. 2016b. Eficiência de fungicidas para controle de Gibberella zeae em trigo: Resultados dos Ensaios Cooperativos-Safra 2015. Comunicado Técnico 368. Embrapa Trigo, Passo Fundo, RS, Brazil.
Santana, F. M., Lau, D., Sbalcheiro, C. C., Schipanski, C. A., Seixas, C. D. S., Feksa, H., Floss, L. G., Guterres, C. W., and Venâncio, W. S. 2016c. Eficiência de fungicidas para controle de Gibberella zeae em trigo: Resultados dos Ensaios Cooperativos-Safra 2014. Comunicado Técnico 364. Embrapa Trigo, Passo Fundo, RS, Brazil.

Savary, S., Nelson, A. D., Djurle, A., Esker, P. D., Sparks, A., Amorim, L., Filho, A. B., Caffi, T., Castilla, N., Garrett, K., McRoberts, N., Rossi, V., Yuen, J., and Willocquet, L. 2018. Concepts, approaches, and avenues for modelling crop health and crop losses. Eur. J. Agron. 100:4-18.

Schaafsma, A. W., Tamburic-Ilinic, L., Miller, J. D., and Hooker, D. C. 2001. Agronomic considerations for reducing deoxynivalenol in wheat grain. Can. J. Plant Pathol. 23:279-285.

Schaafsma, A. W., Tamburic-Ilincic, L., and Hooker, D. C. 2005. Effect of previous crop, tillage, field size, adjacent crop, and sampling direction on airborne propagules of Gibberella zeae/Fusarium graminearum, Fusarium head blight severity, and deoxynivalenol accumulation in winter wheat. Can. J. Plant Pathol. 27:217-224.

Shah, D. A., Molineros, J. E., Paul, P. A., Willyerd, K. T., Madden, L. V., and De Wolf, E. D. 2013. Predicting Fusarium head blight epidemics with weather-driven pre- and post-anthesis logistic regression models. Phytopathology 103:906-919.

Shah, L., Ali, A., Yahya, M., Zhu, Y., Wang, S., Si, H., Rahman, H., and Ma, C. 2018. Integrated control of Fusarium head blight and deoxynivalenol mycotoxin in wheat. Plant Pathol. 67:532-548.

Sharma, R. C., Duveiller, E., and Ortiz-Ferrara, G. 2007. Progress and challenge towards reducing wheat spot blotch threat in the Eastern Gangetic Plains of South Asia: Is climate change already taking its toll? Field Crops Res. 103:109-118.

Spolti, P., Del Ponte, E. M., Dong, Y., Cummings, J. A., and Bergstrom, G. C. 2014. Triazole sensitivity in a contemporary population of Fusarium graminearum from New York wheat and competitiveness of a tebuconazoleresistant isolate. Plant Dis. 98:607-613.

Spolti, P., Shah, D. A., Fernandes, J. M. C., Bergstrom, G. C., and Del Ponte, E. M. 2015. Disease risk, spatial patterns, and incidence-severity relationships of Fusarium head blight in no-till spring wheat following maize or soybean. Plant Dis. 99:1360-1366.

Viechtbauer, W., and Cheung, M. W. L. 2010. Outlier and influence diagnostics for meta-analysis. Res. Synth. Methods 1:112-125.

Wegulo, S. N., Baenziger, P. S., Hernandez Nopsa, J., Bockus, W. W., and Hallen-Adams, H. 2015. Management of Fusarium head blight of wheat and barley. Crop Prot. 73:100-107.

Wegulo, S. N., Bockus, W. W., Nopsa, J. H., De Wolf, E. D., Eskridge, K. M., Peiris, K. H. S., and Dowell, F. E. 2011. Effects of integrating cultivar resistance and fungicide application on Fusarium head blight and deoxynivalenol in winter wheat. Plant Dis. 95:554-560.

Willyerd, K. T., Li, C., Madden, L. V., Bradley, C. A., Bergstrom, G. C., Sweets, L. E., McMullen, M., Ransom, J. K., Grybauskas, A., Osborne, L., Wegulo, S. N., Hershman, D. E., Wise, K., Bockus, W. W., Groth, D., Dill-Macky, R., Milus, E., Esker, P. D., Waxman, K. D., Adee, E. A., Ebelhar, S. E., Young, B. G., and Paul, P. A. 2012. Efficacy and stability of integrating fungicide and cultivar resistance to manage Fusarium head blight and deoxynivalenol in wheat. Plant Dis. 96:957-967.

Wood, S. N. 2017. Generalized Additive Models: An Introduction with R, 2nd ed. Chapman and Hall CRC, New York, NY, U.S.A. 